\title{
Overview on Uranium with Emphasis on Surficial Uranium Deposits in Egypt
}

\author{
Sofia Yahia Afifi \\ Nuclear Materials Authority P.O.Box 530 El Maadi, Egypt.
}

\begin{tabular}{l} 
ART ICLE IN \\
\hline Article history: \\
Received: $9^{\text {th }}$ June 202 \\
Accepted: $15^{\text {th }}$ July 202 \\
\hline Keywords: \\
Uranium, \\
Primary, \\
Secondary, \\
Surficial deposits, \\
Controlling factors, \\
Egypt.
\end{tabular}

\section{1- INTRODUCTION}

Uranium (U) is a naturally occurring heavy metal with unusual properties. It is one of the radiochemical elements in the periodic table, with highest atomic weight $(\sim 238 \mathrm{~g} / \mathrm{mole})$ and is slightly radioactive. It was named after the planet Uranus. It is a hard, dense, malleable, ductile, and silver-white. Uranium has very high density when finely divided, and it can react with cold water.

A uranium atom has 92 proton and 92 electrons of which 6 are valence electrons. Uranium is weakly radioactive since all isotopes of uranium are unstable. The most common isotopes are ${ }^{238} \mathrm{U}$ and ${ }^{235} \mathrm{U}$. In nature, the abundance of ${ }^{238} \mathrm{U}$ is $99.27 \%$ and that of ${ }^{235} \mathrm{U}$ is $0.72 \%$ together with trace amounts of ${ }^{234} \mathrm{U}\left(6.0 \times 10^{-3} \%\right)$. Uranium decays slowly by emitting an alpha particle. The half-life of ${ }^{238} \mathrm{U}$ is about 4.47 billion years and that of ${ }^{235} \mathrm{U}$ is 704 million years. A unique property of ${ }^{235} \mathrm{U}$ is the only naturally occurring fissile isotope which was widely used in nuclear power plants.
The radiation hazards of uranium is rather limited, however its decay products specially radon can built up especially in confined spaces such as closed rooms or basements. This can represents radiation hazards to human. Uranium in air exists as dust that will fall into surface water and plants or on soils through settling or rainfall. Water containing low amounts of uranium is usually generally safe. Uranium concentrations are often higher in phosphate-rich soil, but this does not have to be a problem, since its concentrations often do not exceed normal ranges for uncontaminated soil. Plants absorb uranium through their roots and store it there. Subsequently, root vegetables such as radishes may contain higher than usual concentrations of uranium. However, when the vegetables are washed the uranium will be easily removed.

Within these merits, the present overview is directed to address the basic concepts of uranium deposition and its classification and a brief account on mining and refining of uranium deposits, also definitions of uranium 
minerals, with special emphasis on surficial uranium deposits are. Finally, comprehensive outline on surficial depositions in Egypt is given.

\section{2-Uranium in Geologic Materials}

Uranium is one of the more common elements in the Earth's crust with concentration $4 \mathrm{ppm}$, being 40 times more common than silver and 500 times more common than gold, it can be found almost everywhere in rock, soil, rivers, and oceans[1] . The uranium concentrations in different geologic materials are given in Table (1).

\subsection{Mining and refining}

Uranium is detected due to its radioactivity. It can be mined by in-situ leaching (57\% of world production) or by conventional underground or open-pit mining of ores (43\% of production), depending on the depth of the ore body. Sedimentary-type deposits are usually mined by in situ leaching, during in-situ mining; a leaching solution (acidic or alkaline solution) is pumped down drill holes into the uranium ore deposit where it dissolves the ore minerals. Granitic deposits are mined by taking rocks with the ore from the ground. The first step in processing the uranium is to crush and grind the ore materials to a uniform particle size, mixing these fine-sized particles with water produces slurry of fine ore particles suspended in water. This slurry is then leached with either an acid or an alkali which causes the uranium to dissolve into the solution. This solution is filtered to remove any remaining solids and the uranium is recovered by techniques using solvent extraction, ion exchange or direct precipitation. Finally the uranium is recovered in a chemical precipitate, which is filtered and dried to produce a yellow powder known as yellowcake. If the yellowcake is heated to $700^{\circ} \mathrm{C}$ then it produces a dark grey-green uranium oxide powder concentrating more than $98 \% \mathrm{U}_{3} \mathrm{O}_{8}$.

Yellow uranium cake is a type of concentrated uranium powder that is insoluble in water and contains about $80 \%$ of uranium. It is prepared by means of filtration solutions in an intermediate step in the treatment of uranium ores. It is a step in the processing of uranium after it has been mined but before fuel fabrication or uranium enrichment (Figs. 1 and 2). Yellowcake concentrates are prepared with different extraction and purification methods, depending on the types raw materials (Fig.3). Yellowcake becomes enriched uranium and can be used to prepare fuel for nuclear reactors, but it can also be enriched with the aim of making a nuclear weapon.
Table (1): Uranium concentrations (U ppm) in Geologic materials [2]

\begin{tabular}{|c|c|}
\hline Material & Concentration ( $\mathbf{U}$ ppm) \\
\hline Average earth crust & 1.7 \\
\hline Oceanic crust & 0,5 \\
\hline Upper continental crust & 2.7 \\
\hline Average granite rock & $3.5-4$ \\
\hline Average granodiorite rock & 2.0 \\
\hline Average basalt rock & 0.3 \\
\hline Syenitic rock & 3 \\
\hline Average uranium in volcanic rock & $20-200$ \\
\hline Average uranium in sedimentary rock & 2 \\
\hline Shale ( common) & 3.7 \\
\hline black shale & $3.2-1250$ \\
\hline Sandstones & $0.45-3.2$ \\
\hline Average limestone rock & 2.2 \\
\hline Marine phosphate rocks & $50-300$ \\
\hline Evaporites rocks & $0.01-0.43$ \\
\hline Seawater & 0.003 \\
\hline Groundwater & $>0.001-8$ \\
\hline Petroleum & 0.1 \\
\hline
\end{tabular}

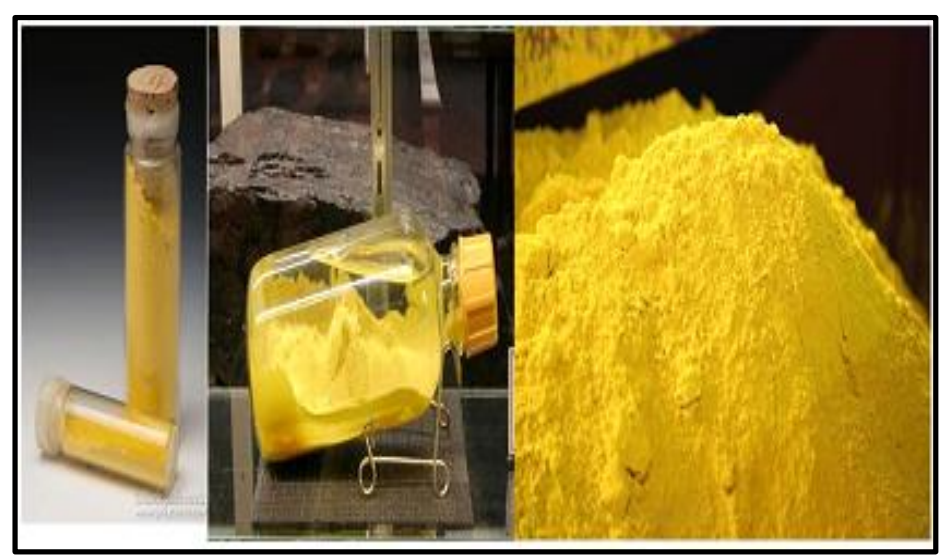

Fig. (1): The uranium solution from the mines is then separated, filtered and dried to produce uranium oxide concentrate, often referred to as "Yellowcake" 


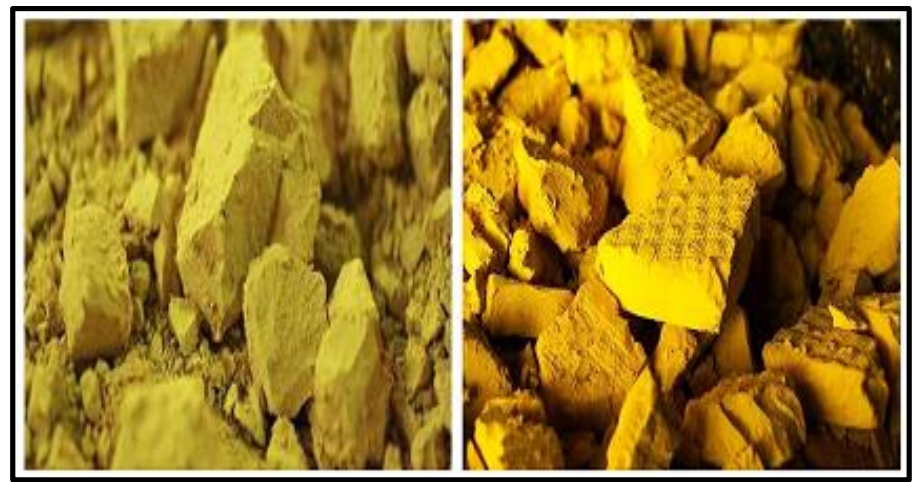

Fig. (2): Yellowcake uranium, a solid form of uranium oxide produce from uranium ore

Yellowcake is the end-product of the in-situ leaching processor before it is made into nuclear fuel (Kazakhstan)

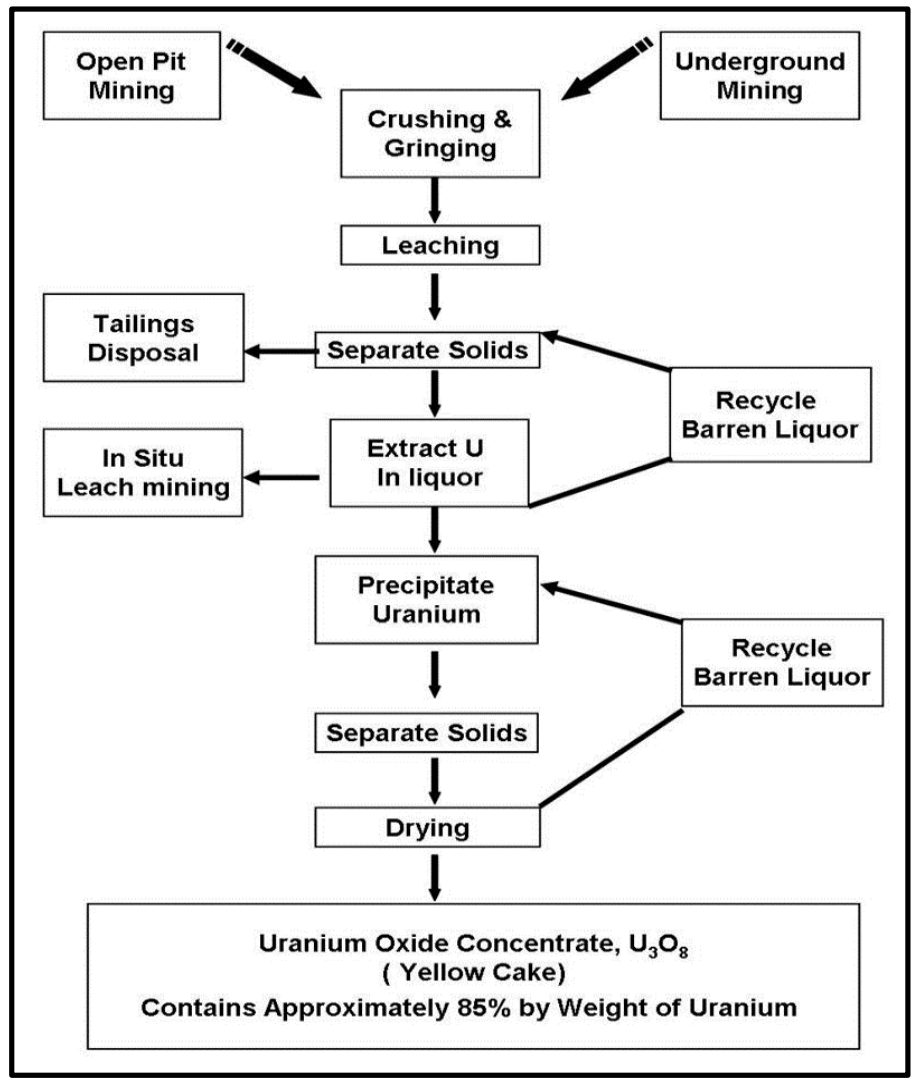

Fig. (3): Flow sheet uranium refining

\section{3-Uranium Ores}

Uranium ore deposits are distributed on all continents, where the largest deposits found in Australia, Kazakhstan, and Canada. The primary uranium minerals are pitchblende, uraninite, davidite, coffinite, and brannerite. They formed by very deep hot solutions and are most commonly found in veins and pegmatites. The secondary uranium minerals altered from the primary uranium minerals by weathering processes, these minerals are carnotite, tyuyamunite and metatyuyamunite, torbernite and metatorbernite, autunite and meta-autunite, and uranophane

\section{1-Uranium Deposition}

The uranium concentrated in one area by two main ways to be considered an ore. The first is sedimentary deposition and the second is granitic deposition. In case of sedimentary deposition, uranium collected in areas where oxygen is absent, such as in rocks which are rich in organic matter. If the oxidizing fluids move, they mobilize the uranium and concentrate it in front of the moving fluids. This process may also occur under a thick layer of sedimentary rock, such as the case of the uranium deposit in Saskatchewan, Canada. In this case the uranium collects between the older bedrock and the sedimentary layers above. While in case of granitic deposition, any trace amounts of uranium become concentrated in the last of fluids left. These metalbearing fluids, invade surrounding rocks with leaving veins with high concentrations of uranium.

\subsection{Classification}

Several classification of uranium deposits have been proposed by different authors[3-9] .While the most recent and comprehensive classification is proposed by another's[10-14].

The OECD / NEA Red Book [15] and The International Atomic Energy Agency (IAEA)[16] classified assigns uranium deposits to 15 main categories of deposit types, according to their geological setting and genesis of mineralization, arranged according to their economic significance for classes of uranium deposits are;
1. Intrusive
2. Granite $(\mathrm{IOCG})=$ Iron oxide - Copper - Gold $)$
4. Volcanic
5. Metamorphic
6. Metasomatite
7. Proterozoic unconformity
8. Collapse breccia pipe
9. Sandstone
10. Paleo- quartz -pebble conglomerate
11. Surficial deposits
12. Lignite and coal
13. Carbonate
14. Phosphorite
15. Black shale

3. Polymetallic iron- oxide breccia complex

These 15 categories was further classified[17] according to their environment to a more convenient classification as given in Table (2).The IAEA classification scheme works well, but is far from ideal, as it does not consider that similar processes may form many types of sediments in a different geological environment. 
The following table shows the types of deposits mentioned above based on their deposition environment.

Table (2): Classification of uranium deposit [17]

\begin{tabular}{c|l}
\hline $\begin{array}{c}\text { Uranium transport } \\
\text { /precipitation conditions }\end{array}$ & \multicolumn{1}{c}{ Deposit type } \\
\hline Surface processes / synsedimentary & - Surficial deposits \\
- Quartz-pebble conglomerate & - Phosphorite deposits \\
& - Lignite and coal \\
& - Black shale deposits \\
\hline Diagenetic & - Sandstone deposits \\
\hline Diagenetic- hydrothermal & - Unconformity - related deposits \\
& - Vein deposits \\
& - Collapse breccia pipe deposits \\
\hline Magmatic - hydrothermal & - Breccia complex deposits \\
& - Volcanic deposits \\
& - Metasomatite deposits \\
& - Vein deposits \\
& - Intrusive deposits \\
\hline Metamorphic - hydrothermal & - Metamorphic deposits \\
\hline
\end{tabular}

\section{4- Uranium Minerals}

Based on Mineralogy of Database 2009, different primary and secondary minerals are given in Table (3). However, in the following the main properties of these minerals are reported in the following sections.

\section{1-Primary Uranium Minerals Properties}

The primary uranium minerals weather and break down very easily when exposed to water and oxygen to produce numerous "secondary" (oxidized minerals, such as carnotite and autunite). Uranium is also found in small amounts in other minerals: allanite, xenotime, monazite, zircon, apatite and sphene. The primary uranium minerals are uraninite $\left(\mathrm{UO}_{2}\right)$ or pitchblende $\left(\mathrm{UO}_{3}, \mathrm{U}_{2} \mathrm{O}_{5}\right)$, collectively referred to as $\mathrm{U}_{3} \mathrm{O}_{8}$ (the most stable form), coffinite, brannerite and davidite..

Uraninite $\left(\mathrm{UO}_{2}\right)$, the most important ore of uranium, it received its name from its uranium content. Uraninite is highly radioactive; it is not a suitable mineral for classroom use. Its chemical composition is $\mathrm{UO}_{2}$, but the chemical composition and mineralogical of the samples varies in response to their levels of oxidation and radioactive decay. Uraninite has a widespread occurrence in nature; it occurs in small amounts in pegmatites and is closely associated with the massive variety pitchblende (Fig 4).

\section{Pitchblende $\left(\mathrm{U}_{3} \mathrm{O}_{8}\right)$}

Pitchblende's (uranium oxide, a botryoidal variety of uraninite), its name was derived from the word pitch (because of its black colour) and blende, a term used by German miners to denote minerals whose density suggested a metal content. It is black to greenish brown uranium mineral and in its massive form; it commonly has a grape-cluster appearance. Pitchblende is lighter than uraninite, having a specific gravity between 6 and 9, it usually contains lead, thorium, rare-earth elements, and it is frequently associated with silver.

Table (3): Uranium Minerals [18]

Primary uranium minerals

\begin{tabular}{l|l|c}
\hline \multicolumn{1}{c|}{ Name } & \multicolumn{1}{|c}{ Chemical Formula } & \multicolumn{1}{c}{ (\%) Uranium } \\
\hline Uraninite & $\mathrm{UO}_{2}$ & $45-85$ \\
\hline Pitchblende & $\mathrm{U}_{3} \mathrm{O}_{8}$ & Variable \\
\hline Coffinite & $\mathrm{U}\left(\mathrm{SiO}_{4}\right)_{1-\mathrm{x}}(\mathrm{OH})_{4 \mathrm{x}}$ & ---- \\
\hline Brannerite & $(\mathrm{U}, \mathrm{Ca}, \mathrm{Ce})(\mathrm{Ti}, \mathrm{Fe})_{2} \mathrm{O}_{6}$ & $\mathrm{Ca} .40$ \\
\hline Davidite & $\mathrm{La}, \mathrm{Ce}, \mathrm{Ca})(\mathrm{Y}, \mathrm{U})\left(\mathrm{Ti}_{1}, \mathrm{Fe}^{3+}\right)_{20} \mathrm{O}_{38}$ & ---- \\
\hline
\end{tabular}

Secondary uranium minerals

\begin{tabular}{l|l|c}
\hline \multicolumn{1}{c|}{ Name } & \multicolumn{1}{|c}{ Chemical Formula } & \multicolumn{1}{|c}{$(\boldsymbol{c})$ Uranium } \\
\hline Autunite & $\mathrm{Ca}\left(\mathrm{UO}_{2}\right)_{2}\left(\mathrm{PO}_{4}\right)_{2} 10 \mathrm{H}_{2} \mathrm{O}$ & $45-55$ \\
\hline Carnotite & $\mathrm{K}_{2}\left(\mathrm{UO}_{2}\right)_{2}\left(\mathrm{VO}_{4}\right)_{2} .3 \mathrm{H}_{2} \mathrm{O}$ & 55 \\
\hline Gummite & gum like mixture of various uranium minerals & ---- \\
\hline Torbernite & $\mathrm{Cu}\left(\mathrm{UO}_{2}\right)_{2}\left(\mathrm{PO}_{4}\right)_{2} .8-12 \mathrm{H}_{2} \mathrm{O}$ & 50 \\
\hline Tyuyamunite & $\mathrm{Ca}\left(\mathrm{UO}_{2}\right)_{2}\left(\mathrm{VO}_{4}\right)_{2} .5-8 \mathrm{H}_{2} \mathrm{O}$ & 50 \\
\hline Uranophane & $\mathrm{Ca}\left(\mathrm{UO}_{2}\right)_{2}\left(\mathrm{SiO}_{3} \mathrm{OH}\right)_{2} .5 \mathrm{H}_{2} \mathrm{O}$ & 57 \\
\hline Saleeite & $\mathrm{Mg}\left(\mathrm{UO}_{2}\right)_{2}\left(\mathrm{PO}_{4}\right)_{2} .10 \mathrm{H}_{2} \mathrm{O}$ & ---- \\
\hline Schroeckingerite & $\mathrm{NaCa}\left(\mathrm{UO}_{2}\right)\left(\mathrm{CO}_{3}\right)_{3}\left(\mathrm{SO}_{4}\right) \mathrm{FOH}_{2} \mathrm{O}$ & ---- \\
\hline
\end{tabular}




\section{Brannerite (U,Ca,Ce)(Ti,Fe) ${ }_{2} \mathrm{O}_{6}$}

Brannerite (uranium titanate) is among the major uranium-bearing minerals found in ore deposits; it is used as a major ore of radium and uranium it is considered as a source of helium. The mineral may be black but it is also found yellow to brown to green colour. It may also fluoresce under a short-wave ultraviolet light. It is also found in different geological environments with the most common occurrences being hydrothermal and pegmatitic.

\section{Coffinite $\mathrm{U}\left(\mathrm{SiO}_{4}\right)_{1-\mathrm{x}}(\mathrm{OH})_{4 \mathrm{x}}$}

Coffinite (uranium silicate), it is black in colour due to the organic matter. It contains over $72 \%$ uranium but it is extremely rare. Coffinite is found associated with uraninite and usually mixed with black vanadium minerals and fine grained carbonaceous material, it is also found in pitchblende veins. Because of its close association and apparent physical similarity with uraninite, its identification is of no practical concern to the searcher.

\section{Davidite $\mathrm{La}, \mathrm{Ce}, \mathrm{Ca})(\mathrm{Y}, \mathrm{U})\left(\mathrm{Ti}, \mathrm{Fe}^{3+}\right)_{20} \mathrm{O}_{38}$}

Davidite is a rare earth oxide mineral and exists in two forms: davidite-La and davidite-Ce, which contain lanthanum and cerium respectively. It forms in uranium bearing pegmatites and has a non-crystalline, glossy black or brownish appearance.

Davidite occurs in hydrothermal veins of high temperature and pressure having the same characteristics of pegmatite's. Such veins occur in gneisses and schists, sometimes in gabbro and anorthosite also. It is associated with limonite, hematite, mica, quartz and pink feldspar. It is never found as a pure mineral, rather as complex intergrowths with ilmenite which has similar physical properties and chemical composition.

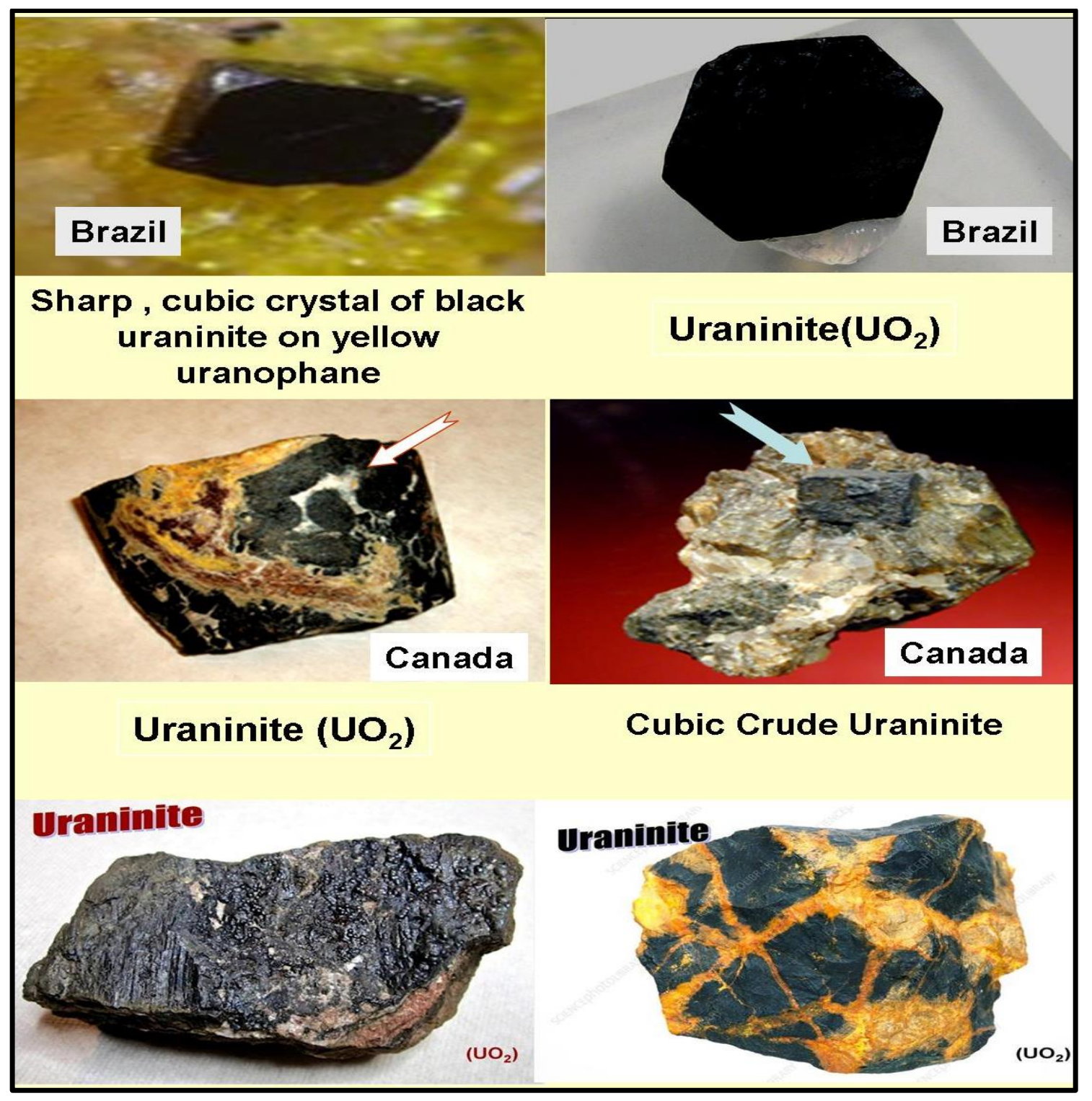

Fig. (4): Primary uranium minerals 


\subsection{Secondary Uranium Minerals Properties}

The secondary uranium minerals are brilliantly coloured and fluorescent, can be found in various deposits. They present in bright yellow, orange, green, and all of the combinations and in-between shades of those colors. Some secondary uranium minerals have the property of fluorescence under ultraviolet light. The secondary uranium minerals have two major modes of occurrence:

1. In the oxidized zones of primary deposits, where they are formed by decomposition of the primary uranium minerals present in place.

2. As irregular, flat-lying deposits in sedimentary rocks, primarily sandstones, conglomerates, shales, and limestones, which formed by precipitation from solutions that may have carried the uranium few distance away from the original source. The most common secondary uranium minerals are:

Gummite (a uraninite alteration product, Lacks definitive chemical formula), is a yellow oxidation product of uraninite (Fig. 5). It consists of uranium oxides, silicates and hydrates; its yellow color is often an indication that primary uranium minerals are close by .When uraninite is found in surface or near-surface deposits, it may have been subjected to weathering, a yellow weathering product gummite is often present.

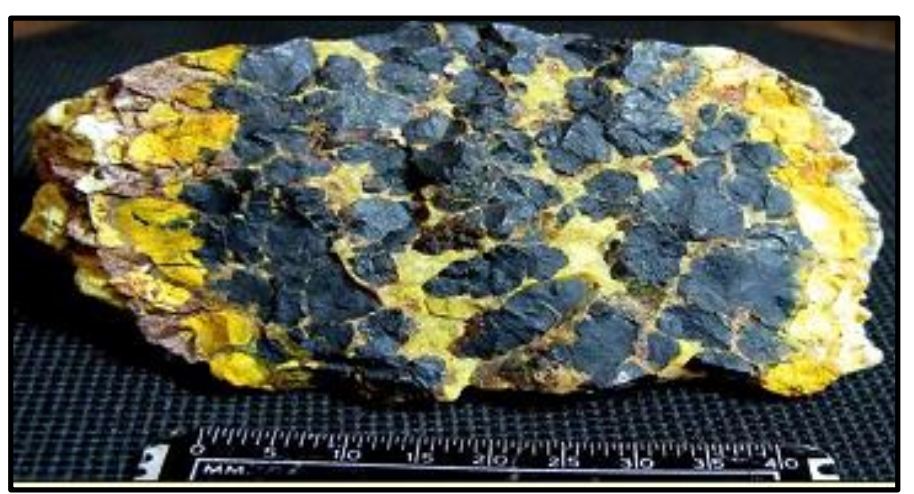

Fig. (5): Black uraninits surrounded by yellow gummite minerals

Autunite and Meta-autunite $\mathrm{Ca}\left(\mathrm{UO}_{2}\right)_{2}\left(\mathrm{PO}_{4}\right)_{2} 10 \mathrm{H}_{2} \mathrm{O}$ $60 \% \mathrm{U}_{3} 0_{8}$. have the same chemical formula of torbernite, with calcium substituting for copper. Because of this similarity, they are commonly found together, the proportion of torbernite being dependent upon the quantity of copper available to the uranium-bearing solutions (Fig. 6).
Uranophane $\mathrm{Ca}\left(\mathrm{UO}_{2}\right)_{2}\left(\mathrm{SiO}_{3} \mathrm{OH}\right)_{2} .5 \mathrm{H}_{2} \mathrm{O} ; 65 \%$ $\mathrm{U}_{3} 0_{8}$ Uranophane is a hydrated calcium uranium silicate containing silica in place of the phosphate of autunite. It is lighter in color and somewhat heavier than autunite (specific gravity 3.85 ) and has a different crystalline form; it may occur as stains or coatings without apparent crystal form or as finely fibrous or radiating crystal aggregates (Fig.6).

Saleeite $\mathrm{Mg}\left(\mathrm{UO}_{2}\right)_{2}\left(\mathrm{PO}_{4}\right)_{2} \cdot \mathbf{1 0}\left(\mathrm{H}_{2} \mathrm{O}\right)$, is a secondary uranium mineral occurring in the oxidized zones of uranium deposits, or as disseminations in carnotitebearing sandstones (Fig. 6).

Torbernite and Meta-torbernite $\mathrm{Cu}\left(\mathrm{UO}_{2}\right)_{2}\left(\mathrm{PO}_{4}\right)_{2}$. 8-12 $\left.\mathrm{H}_{2} \mathrm{O} ; 60 \% \mathrm{U}_{3} \mathrm{O}_{8}\right)$. Torbernite and meta-torbernite are hydrous copper uranium phosphates, the only difference between the two minerals is the number of water molecules present; their physical properties are identical to torbernite and meta-torbernite minerals which are the most common of the secondary uranium minerals that are found associated with primary deposits where oxidation has occurred (Fig. 7).

Carnotite $\left.\mathrm{K}_{\mathbf{2}}\left(\mathrm{UO}_{2}\right)_{\mathbf{2}}\left(\mathrm{VO}_{4}\right)_{2} \mathbf{. 3} \mathbf{H}_{\mathbf{2}} \mathrm{O} ; 50-55 \% \mathrm{U}_{3} \mathrm{O}_{8}\right)$. Carnotite is a potassium uranium vanadate, is the most important of the secondary uranium ore minerals, having provided possibly $90 \%$ of the uranium production from secondary deposits. It is a lemon-yellow mineral with an earthy luster, a yellow streak, and a specific gravity of about 4 (Fig. 7).

Tyuyamunite $\quad \mathbf{C a}\left(\mathrm{UO}_{2}\right)_{2}\left(\mathrm{VO}_{4}\right)_{2}$.5-8 $\quad \mathbf{H}_{2} \mathrm{O} ; \quad 48-55$ $\left.\% \mathrm{U}_{3} \mathrm{O}_{8}\right)$. Tyuyamunite is closely related to carnotite as indicated by the same chemical formula, except that calcium substitutes for the potassium of carnotite. Also the physical properties of tyuyamunite are the same where the greenish color is slightly more than carnotite and, in some cases, a very weak yellow-green fluorescence not found in carnotite (Fig. 7).

Schroeckingerite $\left[\mathrm{NaCa}_{3}\left(\mathrm{UO}_{2}\right)\left(\mathrm{CO}_{3}\right)_{3}\left(\mathrm{SO}_{4}\right) \mathrm{FOH}_{2} 0\right.$; $30 \% \mathrm{U}_{3} \mathrm{O}_{8}$ ]. Schroeckingerite is a complex of hydrated sulfate, carbonate, and fluoride of calcium, sodium, and uranium. It has a yellow to greenish-yellow color with a pearly luster, a bright yellow-green fluorescence; it occurs as globular coatings on rock fracture surfaces and is also found on cave and mine walls (Fig. 7). 


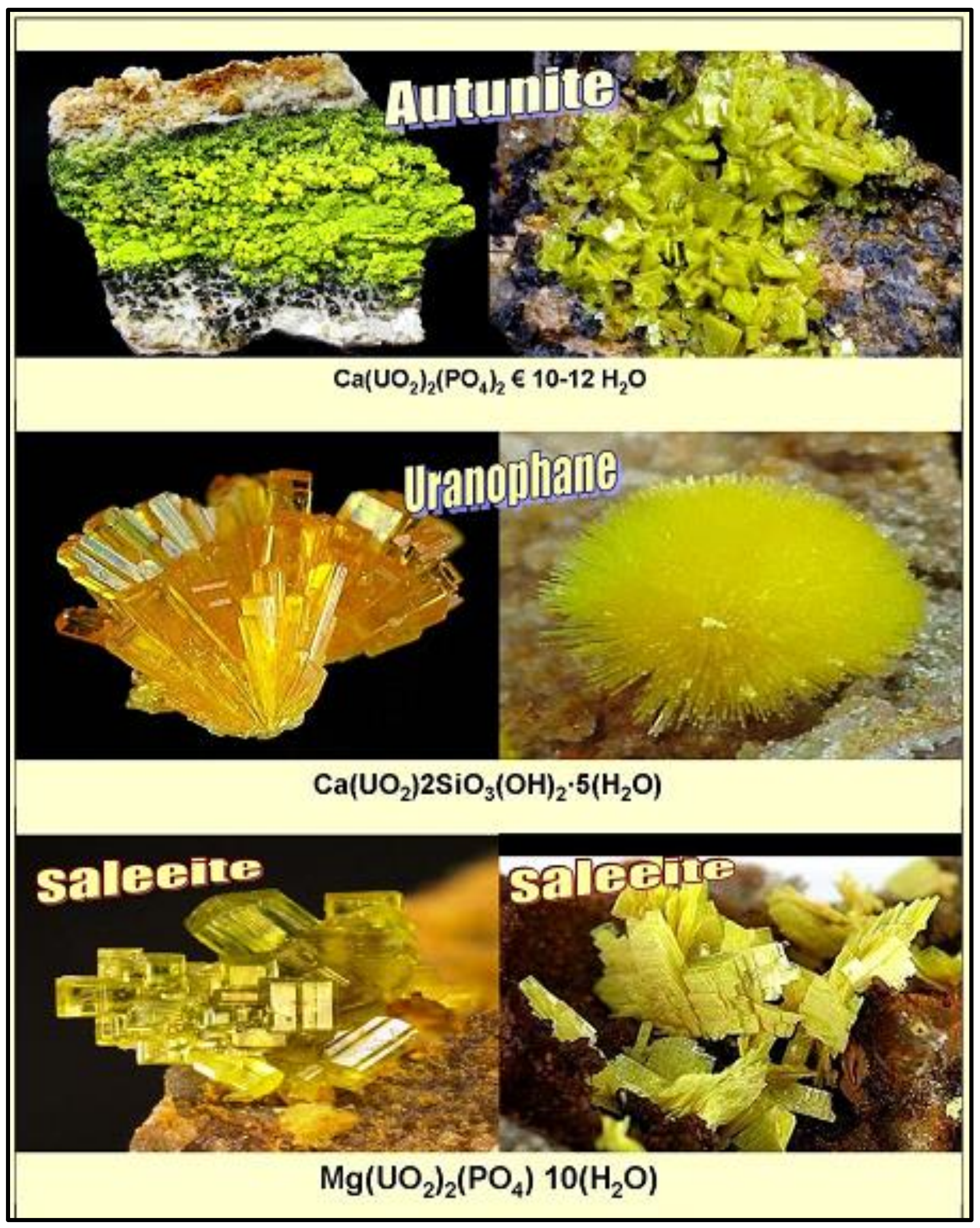

Fig. (6): Secondary uranium minerals 


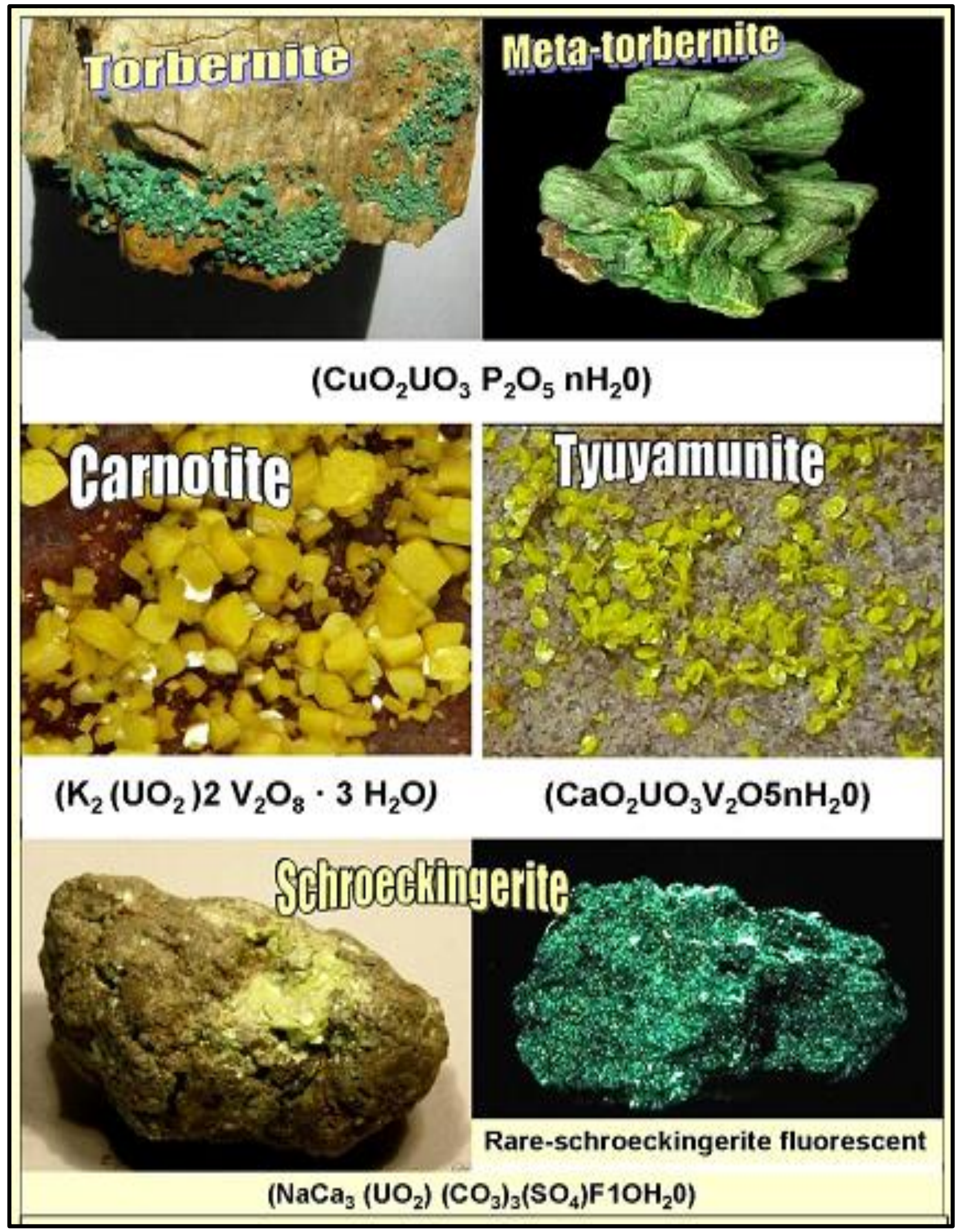

Fig. (7): Secondary uranium minerals 


\section{5- Surficial Uranium Deposits}

Surficial uranium deposits defined as young uraniferous sediments and soils - Tertiary to Recent near surface, ranging from boulder beds to silt have not been subjected to deep burial. Form under varying climatic conditions, having secondary cementing minerals including calcite, dolomite (5 to 50\% - 90\%), ferric oxide and halite [19]. Surficial deposits account for approximately $4 \%$ of world uranium resources [20]. The Yeelirrie deposit in Australia is the largest world's surficial deposit, averaging $0.15 \% \mathrm{U}_{3} \mathrm{O}_{8}$, also Langer Heinrich in Namibia is another significant surficial deposit [19]. Calcrete are the largest type of surficial deposits.

\section{1- Factors Controlling Surficial Deposits}

The major controlling factors effect the world distribution of surficial uranium deposits are: climate, morphology, stratigraphy, permeability and porosity, tectonics, source and transport, mineralogy and geochemistry, evaporation of surface ground water, climatic stability and provenance i.e., the weathering terrane from which uranium and associated substance is derived.

\subsection{1) - Climate}

Surficial uranium deposits seem likely to form under different climatic conditions [21], these are: hot and dry (desert), hot and wet (tropical), temperate and cool (wet lands) and - climates transitional between the first and third.

The rate and type of weathering of uranium source rocks and the rate of mobility of uranium is generally affected by climate [21], climate also determined what type of surficial uranium deposits will form.

In hot desert environment, calcareous dolomite or gypsiferous sediments and certain closed alkaline and saline basins have proved to be the most favourable environment for economic concentration of uranium. In cold temporate climate, the presence of large concentrations of organic matter within a potential orebearing environment is almost required for the occurrence of significant uranium accumulations. Between the two climatic extremes mentioned above, there are many inorganic - organic environments in which surficial uranium deposits may occur [21].

\subsection{2)- Morphology}

Morphology plays a dominant role in the localization of surficial accumulation of uranium; three main types of morphology are conductive to simulate the formation of surficial uranium deposits: a) Closed or partially closed basin (plays, alkaline lakes, deltas, bogs, swamps) in which surface and ground waters are discharged after traversing a source area.

b) Linear depressions characterized by lateral ground water movements (recent and ancient fluvial grain age system

c) Zones within source rock area characterized by vertical ground water and water table fluctuations (e.g., fault, fracture)

\subsection{3) - Stratigraphy}

Stratigraphy is a further physical feature controlling the emplacement of ore clay rich horizons, which generally form aquicludes to ground water, may act as physico - chemical barrier promoting the precipitation of uranium or if more than one horizon is present, many channel led the ground water into area favourable to precipitation of ore (deltaic deposits).

\subsection{4)- Permeability and Porosity}

Permeability and porosity play a major role in ore formation which uranium mineralization precipitation in porous horizons such as the calcareous dolomite, gypsiferous valley and deltaic sediments of arid regions.

\subsection{5) - Tectonics}

The tectonic history and structure frameworks of a region play an important role in the formation of surficial uranium deposits. Tectonic processes such as up lift and or / extensional tectonism prepare the source rock area and depositional one for both surface and ground water leaching of ore forming elements (Fig.8), because the formation of a surficial uranium deposits requires a stable hydrological system and a distinct period of tectonic quiescence is also required [22\& 23].

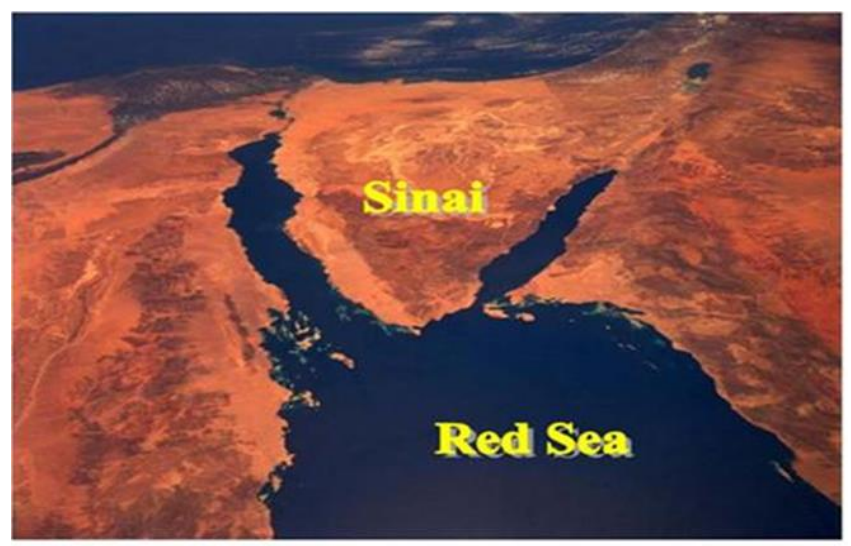

Tectonics As A Controlling Factor

1-Basin configuration

2- Topography relief differences

3- Rate of sedimentation and basin filling.

4- Availability of source feeders (drainages)

5- Availability of restricted areas.

Fig. (8): Tectonic as a control factor

\subsection{6) - Source and Transport}

Arab J. Nucl. Sci. Appl., Vol. 54, 4, (2021) 
Most surficial uranium deposits are near source rocks that are enriched in uranium (significantly greater than $5 \mathrm{ppm}$ ), many deposits have formed in terranes where granites and other rocks appear to have average (1 to $5 \mathrm{ppm}$ ) uranium contents. Additional favourable circumstances such as extensive fracturing may allow sufficient uranium in solution to enter the surficial environment and to be deposits [23-25].

Transport of uranium required oxidizing conditions at the source and in the environments located between the source and the host, transport is less sensitive to the presence of complexes. For virtually all surficial uranium deposits uranium is liberated from source rocks by leaching and is transported by oxidized surface water or shallow ground waters.

In arid lands uranium is generally leached from source by slightly alkaline oxidizing waters and carried as uranyl-carbonate or bicarbonate complexes. Alkalinity and salinity of the waters and oxidizing conditions persist tend to increase down low keeping the uranyl ions in solution till fixation mechanisms intervene.

In tropical environments, the near surface soil horizons are typically acid, uranium is probably complexed by sulphate or phosphate ions. In wetlands the water are usually acid or close to neutral and are relatively fresh but still carry inorganic or organic complexing agents well in excess of any contained uranium.

In tropical and wetland environment transport distances and generally shorts (a meter to few kilometers) whereas in arid lands, transport distances may be long ranges from several tens to kilometers [26].

\subsection{7) - Mineralogy and Geochemistry}

Uranium deposits in desert are generally characterized by carnotite as fracture coating, void filling and less commonly disseminated in the cement. These deposits also contain various amounts of associated authogenic minerals, principally calcite, dolomite, gypsum, silica, halite and clay. The degree of cementation ranges from $5 \%$ to almost complete replacement of the sediment by authogenic material. The host rock is usually zoned mineralogically with respect to the water table or to the surface.

\subsection{8) - Evaporation of Surface Ground Water}

During the evaporation processes, uranium is concentrated in the final bittern residue of alkaline and saline lakes and only precipitates during the final stage of saline pan cycle [27-29]. Evaporation mechanism is responsible for formation of uranium in voids, cavities and fissure under climatic conditions of low rainfall and high average temperature. In the absence of precipitation agents such as $\mathrm{V}$ and $\mathrm{P}$, evaporation is not a particularly good mechanism for concentrating uranium in surficial environment [28].

Uranium will accumulate in reducing black oozes and clay- rich horizons in these environment, and even then only in relatively low concentration due probably to the presence of complexing ions in the associated waters. Evaporation of upwelling ground waters in calcrete gypecrete drainage channels may be partially responsible for localization of carnotite deposits due to increased activity of $\mathrm{U}^{6+}$ and $\mathrm{K}^{+}, \mathrm{V}^{6+}$ above the solubility product of carnotite [30\&31]. The solubility of many uranyl minerals especially carnotite vs. $\mathrm{pH}$ and the stabilities of all uranyl complexes are $\mathrm{pH}$ dependant [30 \& 32].

The formation of ores as a result of $\mathrm{pH}$ changes can be accomplished by such process as:

a- Mixing of two or more surface or ground waters to form a variety of uranium minerals.

b- Loss of $\mathrm{CO}_{2}$ by rising uraniferous ground waters to form carnotite and uraniferous travertine [33].

c- Oxidation of sulphide bodies to form a host of uranyl and uranium silicates, phosphate and arsenate.

d- Reaction with soluble acids in organic (humic fuvic), clay- rich environments where the $\mathrm{pH}$ range from 4 to 7 which is favourable for adsorption.

\section{2.- Case Study}

\section{Mechanism for carnotite precipitation in the calcrete environment}

Carnotite is the only uranium mineral identified by the Staff of Western Mining Corporation or reported by any other investigator at Yeelirrie deposit. The interesting features of the carnotite mineral is the greenish colour, some times it is almost olive green.

The carnotite is clearly one of the last mineral to be deposited, forming a thin film on the walls of voids in the calcrete environment dispersed through the earth calcrete coating fracture planes (Fig. 9).

Carnotite appears to occur in three recognizable modes:

1- As minutely dissiminated grains in muddy calcrete of the "young" mounds and deficient in gamma ray producing daughter products

2- As films of recently deposited bright yellow powdery carnotite deficient in gamma- ray producing daughter products in mature calcrete. 
3- As euhedral to anhedral grain within carbonate nodules on fracture and cavities.

Mann [30] has presented seven hypothetical mechanisms for carnotite precipitation in the calcrete and deltaic - lacustrine environment. Carnotite, the only ore mineral, results from:

1- Addition of potassium or vanadium enriched waters

2- Change the solubility of carnotite with $\mathrm{pH}$ change

3- Change in partial pressure of $\mathrm{CO}_{2}$
4- Carnotite precipitation by evaporative concentration, which play a major role in all forms of calcrete uranium genesis, because it increases the concentration of all components in solution except carbonate species.

5- The precipitation of carnotite through common- ion precipitation of calcite or dolomite

6- Carnotite precipitation through oxidation

7- Absorption and surface catalysis.

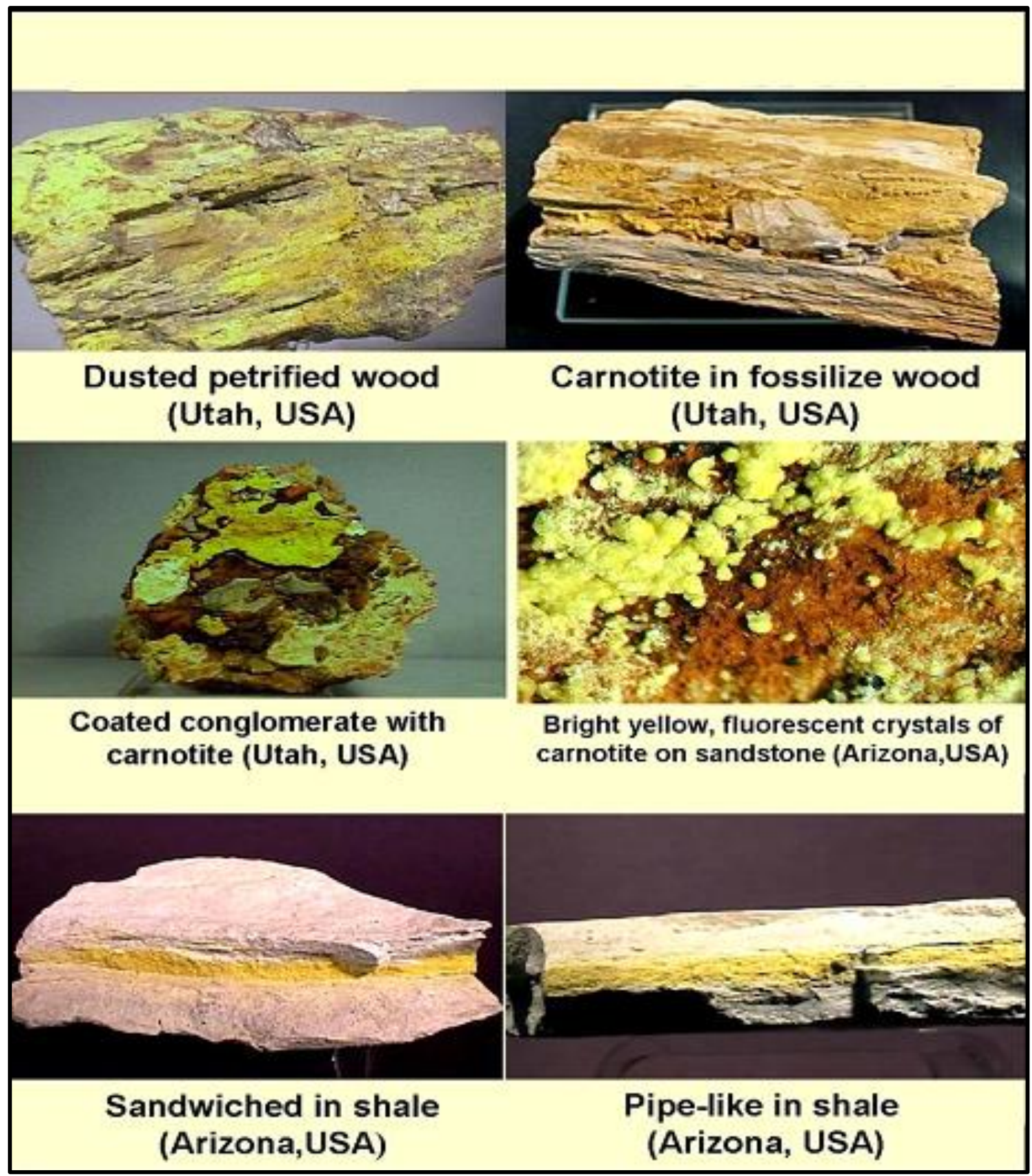

Fig. (9): Different examples of carnotite 


\section{3. - Main Surficial Deposits in Egypt}

Surficial uranium deposits in Egypt could formulate important economic feed for the following:

i- Validity of controlling factors such as climate, source, tectonics, relief difference, closed basin, evaporation processes, influence of organic roles and redox factors.

ii- Reviewed examples in Egypt, suggest the strong probability of surficial uranium existence (Bahariya, Sitra lakes, Fayium, Tushki basins and Ras Shukeir), moreover the Siwa oasis can represent indicative recent simulator for formation processes

iii- Presence of carnotite in Sinai supports the prevalence of similar controlling factors that govern the Australian examples.

\subsection{1. - Probability Versus Reality}

In Egypt the availability of the controlling factors responsible for entrapping and formation of surficial uranium deposits are varied and complex in nature e.g.; climate- structure- slope for wash; rate of weathering and agents; provenance's ; natural and structural basins producing rugged relief; rate of precipitation, etc.

The predominance of dry hot climate characterized the Arab republic of Egypt, summer is hot $\left(\sim 37^{\circ} \mathrm{C}\right)$, and winter is relatively cold $\left(\sim 15^{\circ} \mathrm{C}\right)$, the other two seasons are of temperate weather. The rain precipitation in Egypt is generally $1-3 \mathrm{~mm} / \mathrm{y}$, evaporation rate is very high especially desert areas and is variable within location and seasons. It is clear that during summer months, relatively high temperature lower humidity, no rain falls and high evaporation is predominant. On the contrary during the winter month's relatively lower temperature, higher humidity, less evaporation and high rain fall predominant. Field observation show that during the summer season, higher rate evaporation will led to the concentration of brine followed by precipitation of salts and the net result is the lowering of ground water level, formulating the requirement for sabkhatization processes to be active ( reduce zone, porosity and permeability).

The geomorphology of Egypt is situated in the northeastern corner of the African continent and extends beyond the Gulf of Suez and the Suez Canal into the Asia eastward. Geographically, the country is composed of several distinct regions, namely from east to west:

a) The Sinai Peninsula, the Gulf of Suez and Suez Canal

b) The Eastern Desert with the Red Sea coastal and offshore part

c) The Nile Valley and the Western Desert and each of which has its own geomorphologic units [34]
From the above the conditional climate, geomorphology and structure of the Egyptian tenitory, it can be conclude the following:

i- The Sinai - Eastern Desert basement rocks confined many (may be several) inter-cratonic basin, either closed or even open.

ii- The climate prevailed over the area is generally hot arid and temporary rainy.

iii- The basement rocks especially granite and rhyolite dykes possesses high background content of uranium (up 14 ppm).

iv- Drainage systems are dense enough to transport the leached mineral solution into basins.

\subsection{2.-Review of the Proposed Examples in Egypt}

The surficial deposits are often of limited extent and are located in remote areas; these deposits constitute about $10 \%$ to $15 \%$ of global resources[35]. Due to their mode of formation, many of surficial deposits are likely to occur in remote desert regions and their exploitation could eventually assist in opening up areas, which normally have remained undeveloped.

In Egypt, few studies have been carried about uranium minerals in sedimentary section at some localities in Western Desert and Sinai since 1960,s. Most authors subjected the uranium minerals in the section as lithostratigraphic controls. However in the present time and depending on the uranium deposits classification, it is possible to subject these localities in newly scope as uranium minerals bearing surficial deposits. The following deals with examples of such localities, and can subdivide the proposed examples into two types. The first is examples of indicative shows like Fayium depression, Bahariya sabkha and desert lakes (Sitra and El Bahrein lakes), Bir El Shab in Western Desert, west central Sinai and Ras Shukeir, G.El Zeit in Eastern Desert, while the other is formulating the exploration trend present like in Siwa Oasis.

\section{1- Fayium Depression}

Uranium occurrences at north Fayium depression are hosted within Post-Oligocene sediments occupying low lands and basins (weathering-erosion).The uraniferous sediments are generally composed of siliclastic frame work grains of quartz sand cemented by calcite, goethite, hematite, gypsum and the uranium associated with calcrete, gypecrete, ferricrete[36].

The uranium formation at Fayium depression is controlled by different factors [36], such as: 
1- Climate at Fayium depression is considered a hot and arid, where the rate of movement of uranium- bearing solution from source to site of depression is believed to be slow due to the low rate of precipitation and high rate of evaporation. These conditions are suitable for uranium precipitation with calcite, gypsum and halite as end evaporative yields. The evaporation mechanism controls the formation of uranium in voids, cavities and fissures under arid climatic conditions, whenever low rainfall and high average temperature prevailed

2- Geomorphology plays a dominant role in the localization of surficial accumulations of uranium, the geomorphologic factors in the area are: a) Linear depression (structurally controlled) that formed by the paleo- channeling of the Oligocene sediments, where these channels help in lateral movement of uranium bearing ground water. b) The post Oligocene basins in which ground water discharged and the uraniferous sediments are preserved through formed sporadic evaporative lakes.

3- Evaporation mechanism controls the formation of uranium in voids, cavities and fissures under arid climatic conditions.

4- Leaching of uranium from biological remnants and complete vertebral skeleton of Eocene- Oligocene age, where the natural radioactivity of the bone beds of Fayium is related to uranium (up to $930 \mathrm{ppm}$ ) and not to thorium ( $<9 \mathrm{ppm})$. Leaching of uranium in the bone beds was subjected to the effect of slightly alkaline oxidizing conditions persist and alkalinity with salinity of water tend to keep the uranyl ion in solution until fixation mechanism intervene [37].

5- Remobilization of uranium with other elements carried by running surface waters through the channel system that deposited later.

6- Precipitation and adsorption of uranium by both phosphate and organic matter which indicated by the presence of abundant globular and framboidal pyrite.

\section{2- West Central Sinai}

West Central Sinai reflect most clear locally documented example of the deposition of uranium in surficial sediments. High rugged feature (source), local low land (receiver), drainage system (transportation and leachability) structural control (basins), basement rocks bounding sedimentary facies, climatic condition (evaporation), surface and ground water, gentle to steep slope ( paleotopography) .

The formation of surficial uranium mineral deposited in west central Sinai includes three geochemical processes which favour their deposition namely [38]:

a) Leaching of pre - existing uranium minerals present in the basement complex by circulating meteoric water at high Eh. Due to high concentration of bicarbonate in meteoric waters the dissolved uranium is complexed by formation of uranyl di- carbonate and tri- carbonate complexes[39].

b) After precipitation of calcite and or / dolomite from these solution, the bicarbonate concentration decreased leading to the decomposition of uranyl dicarbonate and tri- carbonate complexes. The released uranium ions then combined with dominant potassium and small amount of vanadium to form potassium uranyl vanadate (carnotite) [40].

c) Trapping of uraniferous solution within suitable geological, structural and lithological sites represented in our area by clays, shale and dolomite association. The clay minerals represent an important stage in uranium concentration [41], where uranium adsorption or co- precipitation by different type of clays especially at alkaline $\mathrm{pH}$ values such as in the evaporitic processes [42].

d) Evaporation and re- deposition processes by the action of percolating waters under arid climatic conditions, which characterized by high average temperature, low average rainfall and low humidity. Similar climatic conditions exist in the calcrete of Western Australia where carnotite mineral is dominating.

\section{Bahariya Oasis}

Bahariya Oasis occupies the depression situated at the faulted crest of large doubly plunging anticline trending NE-SW.

a) The surficial uranium concentrations have been discovered in sabkha deposits occupying the floor of the depression of the Bahariya Oasis [43] e.g.: Ain Giffara (2- 63 ppm), El- Harra sabkhas (2- 20 ppm).

b) The uranium anomalous concentration in the sediments of Ain Giffara and El- Harra sabkhas displays the form of isolated lenses. This form of distribution indicates leaching of uranium from different sources by ground water and re- deposition in different places whenever the physico- chemical conditions are favorable

b) Simple evaporative type environments (open basins of accumulations or playa)

c) The formation of uranium in both areas is probably related into two conditions. The former is controlled by faults system at Baharia Oasis acting as channels through which the surface running water washed the uraniferous phosphate bed and other cretaceous sediments, leached it and redeposit in low land and sabkha lakes (Ain Giffara and El- Harra). The second condition is that the up ward movement of ground water from the aquifer leaching uranium from the rich uranium beds, and carries it upwards where 
reducing condition are present through sequential saturations of the different salt facies.

d) Solar evaporation and biological activities are the main factors.

e) The presence of organic matter in clays and finegrained sediments is considered as important factor in adsorption and fixation of uranium at the sabkhas of Ain Giffara and El-Harra area.

f) The uranium concentration in of Ain Giffara, El- Harra area and Baharia oasis represent a simple evaporative type environment, which characterized of open basins of accumulations of playa. The source of uranium is suggested to be the phosphatic layers in the scarps surrounding the oasis depression [44].

\section{4- Sitra Saline Lake}

The natural saline lakes which lie in the northern Western Desert are example for surficial uranium occurrences associated with sabkha deposits.

a) It represents the evaporitic type deposits that influenced by cyanobacteria activities in organo salinas media respect to the time of development. It subdivided into five zones; each one has its own sedimentological characteristic and products. These subdivisions reflect the effect of the physicochemical parameters comprise high temperature, scarce rain fall, humidity, input rate, upward pumping mechanism and slope are responsible for sabkha profile formation.

b) The cyanobacteria (anaerobism) and organic matter with their effect on the $\mathrm{pH}$ in addition to the evaporative pumping mechanisms are the main factors to entrapment and enrichment the radioactive factors elements in saline environments [45].

c) Topography is another supplementary factors, where it will serve (wherever mobilization as diagenetic effects) to allocate the trend for concentration radioactive elements in the lower topography. The results indicate increase in uranium concentration along the horizontal and vertical distribution heading farther from the recharge source.Also this indicates that the increase in salinity gradient farther from the feading source has its role in entrapping radioactive elements [45]

\section{The diagenetic effects started leading to:}

1- Development of reducing conditions due to cyanobacteria effect (anaerobism), followed by degradation and mineral alteration (Fig. 10).

2- Mobilization stages for $U$ as indicated by the studied vertical trenches and auger sites in the area.

3- Leaching down slope for the mobile $U$ to the lower topography, where $\mathrm{U}$ concentration supports the view [45].

\section{5- Siwa Oasis}

Siwa Oasis is the strong probability of surficial uranium existence, in the last three decades witness over - pumping that led to saline pooling surrounding the Oasis, near by sources in calcrete of El- Moghra formation would be capture in the newly reducing environs and after " $\mathrm{X}$ " year the Siwa Oasis recent simulator can represent indicative simulator for formation processes (Fig. 11).
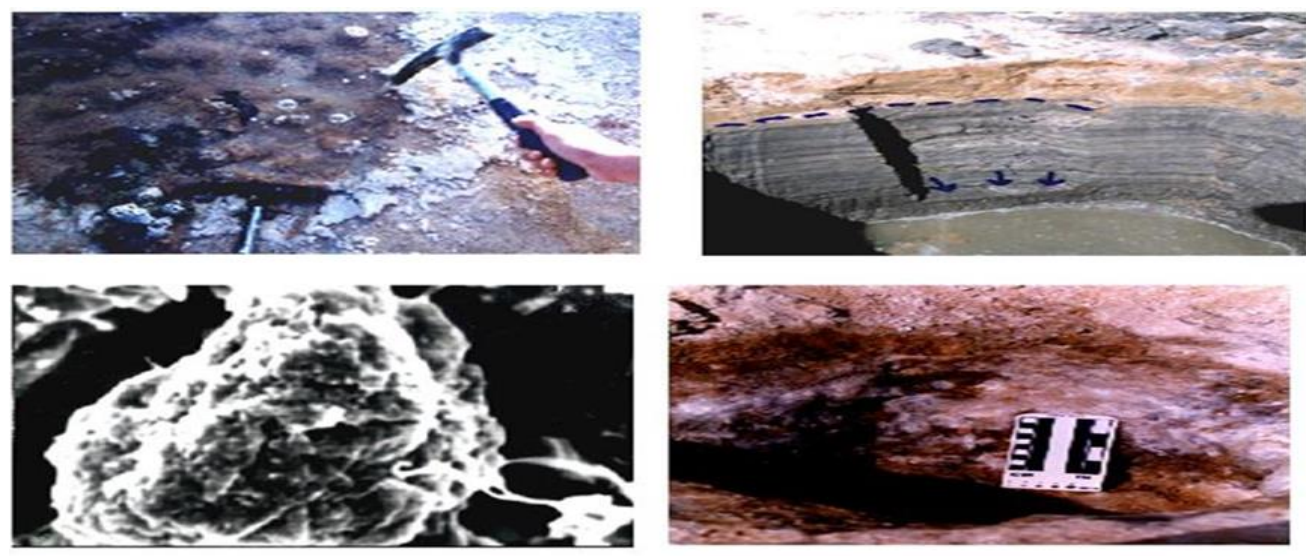

Bio-Leach and Bio-Enrich

Micro-organisms play important roles and responsible for:

1- Predominance of anaerobic bacteria.

2- Controlling and enriching the U-bearing minerals (Bio-enrich) even within micro-

environments.

3-Fixation of the entrapped U minerals in vertical sequences (sabkha).

Fig. (10): Bio-leach and bio-enrich (Sitra lake) 


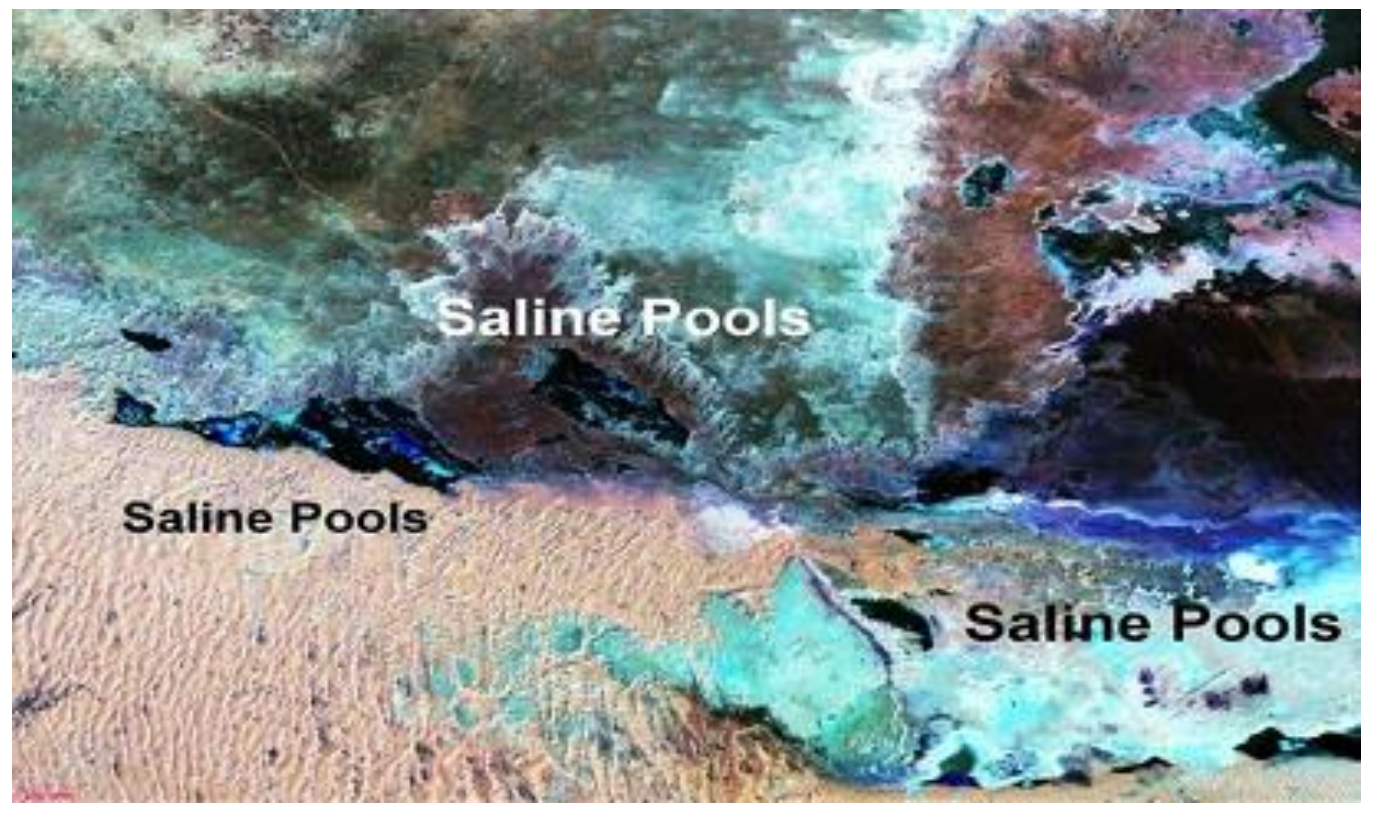

Fig. (11): Siwa Oasis and over- Pumping effects

"A recent simulator"

\section{6- CONCLUSIONS}

The surficial uranium in Egypt could formulate important economic feed for the following points:

\section{1- Validity of controlling factors such as:}

a) Climate (hot arid)

b) Source (basement)

c) Tectonic as controlling factor led difference in relief topography and basin configuration

d) Role of structure control (Rift system) and prevalence of reducing conditions (saline pan), Ras Shukeir is a classic example explaining this effect

e) Evaporation processes and the interaction between basement source carrying waters and evaporative vertical.

f) Micro- organisms which play an important roles and responsible for predominance of anaerobic bacteria controlling and enriching the U- bearing minerals (Bio- enrich) even within microenvironments and finally fixation of the entrapped $U$ - minerals in vertical sequences ( Fig.10) .

6.2- Presence of carnotite in Sinai support the prevalence of similar controlling factors governs the Australia examples.

\section{7-REFERENCES}

[1] Cameco- Uranium 101," Where is uranium found?". Retrieved 2009-01-28.
[2] T.K., Kyser, M.Cuney; Mineralogical Association of Canada Montreal, Quebec (46), 3, 39-84(2015)

[3] J. T.,Nash, H.C. Granger and S.S. Adam; Econ.Geol.75 ${ }^{\text {th }}$, Anniversary, 63, 116 (1981).

[4] F.J.Dahlkamp; "Uranium Ore Deposits", Berlin, Springer-Verlag, 460 (1993).

[5] F.J.Dahlkamp; "Uranium Deposits of the World", Asia, Springer-Verlag Berlin, 493(2009)

[6] OECD / Nuclear Energy Agency;"Uranium, Resources, Production and Demand", OECD, Paris (1994).

[7] O.R. Eskstrand; Canadian mineral deposit types; a geological synopsis. Geol. Surv. Can. Econ. Geol. Rep.36, 86(1984).

[8] J.A. Plant and J. Tarney; Mineral deposit models and primary rock geochemical characteristics. In Handbook of Exploration Geochemistry, Drainage Geochemistry, 6: 11-72 Hale, M, Plant, J. A. (Eds) Elsevier, Amsterdam (1994)

[9] O.R. Eskstrand, W.D. Sinclair and R. I. Thorpe; (1995): Geol. Surv. Can. Geology of Canada, 8, 640 (1995).

[10] M.Cuney; The extreme diversity of uranium deposits. Mineral, Dep. 44, 3-9 (2009)

[11] M.Cuney;. Econ.Geol. 105, 449-465 (2010) 
[12] M.Cuney; Geoscientific and social challenges, International Year of Planet Earth Springer, 91- 129 (2011).

[13] M.Cuney, A.Emetz, J.Mercadier, V.Mykchaylov, V.Shunko, and A.Yuslenko, ; OGR 44, 82- 106 (2012).

[14] M.Cuney andT.K.Kyser; "Uranium Deposit Types": New Classification: Mineralogical Association of Canada, Short Course Series 46, Montreal, Quebec, $2,15-37(2015)$.

[15] OECD / NEA; Uranium, Resources, Production and Demand 1993, OECD, Paris (1994)

[16] IAEA; Resources, Production and Demand, NEA., No. 7209, OECD, 504 (2014).

[17] J.Lally and Z. Bajwah ; Uranium Deposits of the Nt., Northern Territory Geological Survey, 20, ISBNO- 7245- 7107-8(2006).

[18] B.Merkel and B. Sperling; Hydrogeochemische Soffsysteme Teil II, DVWK, ISSN 01708147(1998).

[19] A.D. McKay and Y.Meiitis ; AGSO-Geoscience Australia, (2001),

[20] Geology of Uranium Deposits - World Nuclear Association World-Nuclear.Org. Retrieved 18 April (2018).

[21] D.R. Boyle; (1984): The genesis of Surficial Uranium Deposits. In: Surficial Uranium Deposits. IAEA-TECDOC 322, 45-52(1984).

[22] G Armands; Geochemical prospecting of a uraniferous bog deposit at Masugnsbyn, Northern Sweden, in: Geochemical prospecting in Fennoscandia,Kvalheim, Ed), Interscience Publishers,. 127- 154(1967).

[23] R.R. Culbert D.R. Boyle and A.A. Levinson; Surficial Uranium Deposits in Canada. In Surficial Uranium Deposits, TECDOC- 322. IAEA, Vienna, 179-191(1984).

[24] J. K. Otton; Surficial Uranium Deposits in the United States of America. In: Surficial Uranium Deposits, IECDOC- 322, IAEA, Vienna, 237242(1984a) .

[25] J. K. Otton; Surficial Uranium Deposits: Summary and Conclusions. In: Surficial Uranium Deposits, IECDOC- 322, IAEA, Vienna, 234-247 (1984b).

[26] P. Briot and Y. Fuchs; Processus de Mineralosation Uranifere des Calcretes: Une Hypothese. Non pedologioe. In: Surficial Uranium Deposits, TECDOC- 232, IAEA, Vienna, 15- 24 (1984).

[27] K.G. Bell ; U.S.Geol. Surv.Prof. Paper 354- G, 161-169(1960).

[28] A.V. Kochenov, A. A. Chernikov; Lith. Min., Res., V.11, 110-116 (1976).

[29] R.R. Culbert, D. G. Leighton; Inst. Min. Metal, 71793, 103-110 (1978).

[30] A.W. Mann; CSIRO (Aust. Div. Mineral) Rep. No., FP.7.18 (1974c).

[31] A.W. Mann, and R.L.Deutscher; Econ. Geol. 73, 1724- 1737(1978).

[32] D.Langmuir; Geochim. Cosmochim, Acta, 42, 547569(1978).

[33] V.S. Serebrennikov and L. G. Maksimova; Geochem. Int.S.pp: 167-174,(1976).

[34] P.Schlumberger; Geology of Egypt, Chapter I, Well Evaluation Conference, 1-64 (1984).

[35] P. D. Toens and B. B. Hambleton - Jones; Definition and Classification of Surficial Uranium Deposits, in: Surficial uranium deposits, TECDOC322, IAEA, Vienna, 9-14 (1984).

[36] Y.M.Haroun; Favourable geologic environment for uranium concentration in some areas in the North Western Desert, Egypt, Ph.D. Thesis, Faculty of Science, Cairo University , Egypt, 90 ( 2001).

[37] A. El- Kammer , M. El- Kammer, and I., ElGamal; Proceeding of $5^{\text {th }}$ International Conference on the Geology of the Arab world, Cairo University, 3, 213-238 (2000).

[38] (38)H. Hussein, A. Abd El- Monem , M. Mahdy, I.. El Aassy and G. Dabbour ; Ore Geol. Rev., 7, 125135(1992).

[39] D. Gamble; The Lake Raeside Uranium Deposits, In: Surficial Uranium Deposits, TECDOC, - 322, IAEA, Vienna, 141- 148 (1984).

[40] O. R. Sallam, A.M. Abdrabboh, A.A. Abbas, H. H. Ali and A. S. Alshami; Egyptian Journal of Basic and Applied Sciences, 7, 1, 159-179 (2020).

[41] N. Katayama, K. Kubu and S. Hirono; Proc. Symp., and formation of uranium deposits. Athens, IAEA. Vienna, 437 - 425(1974).

[42] M. Gauthier ; Bull, Surv. Carte. Geol. Alsace lorraine 14, 179 (1961). 
[43] A.M. Morsy; Geology and Radioactivity of Late Cretaceous- Tertiary Sediments in the Northern Western Desert, Egypt, Ph. D. Thesis, Mansoura University, 351 (1987).

[44] Y.M.Haroun; (1990): Geology and Geochemical Studied of the Radioactive Quaternary Deposits, Baharia Oasis, Western Desert, Egypt, M. Sc.
Thesis, Faculty of Science, Ain Shams Univ. Egypt, 184(1990).

[45] S.Y. Afifi; Geology, Mineralogy and Geochemistry of Sabkha Deposits and Associated Uranium Accumulations of Lake El Arag - Lake Sitra area, Northern Western Desert, Egypt. Ph D. Thesis, Cairo University, 126 (1998). 